UDC 577.115.3 : 633.527.2

DOI: $10.15587 / 2519-4852.2021 .243361$

\title{
COMPARATIVE ANALYSIS OF THE FATTY ACID COMPOSITION OF RAW MATERIAL OF RYE (KHAMARKA VARIETY) AND BARLEY (SHEDEVR VARIETY) OF UKRAINIAN SELECTION
}

\author{
Ganna Tartynska, Iryna Zhuravel, Viktoriia Kyslychenko, Viktoriia Hutsol
}

Sowing rye (Secale cereale L.) and common barley (Hordéum vulgáre L.) are annual herbaceous plants of the Poaceae family, they are widely cultivated in many countries around the world as cereals and fodder crops. Sufficient raw material base of sowing rye and barley makes them promising sources for new drugs.

Materials and methods. The fatty acid composition in lipophilic fractions of seeds, stems and leaves of sowing (Khamarka variety) and common barley (Shedevr variety) was studied by gas chromatography.

Results. As a result of the study, the quantitative content of 14 fatty acids in the stems and leaves of barley, 13 - in the leaves of rye and 12 - in the stems of rye and in both types of studied seeds was identified and established. In all types of the studied raw materials, unsaturated fatty acids were quantitatively predominant, the content of which prevailed in seeds of rye - $82.89 \%$ and barley - $76.35 \%$. In stems of common barley their content was $64.04 \%$, leaves of common barley - $66.31 \%$ of the amount. In stems and leaves of rye, the predominance of unsaturated fatty acids over saturated ones was insignificant: $49.00 \%$ vs. $47.05 \%$ and $53.70 \%$ vs. $43.03 \%$, respectively. Among the unsaturated fatty acids, linoleic and linolenic acids dominated. Palmitic acid predominated among the saturated raw materials in all types of studied raw materials

Conclusions. Quantitative content of fatty acids in seeds, stems and leaves of sowing rye (Khamarka variety) and common barley (Shedevr variety) was identified and established by gas chromatography. The results of the research indicate a rich fatty acid composition of the studied raw materials and can be used to create drugs based on them Keywords: Rye (Khamarka variety), common barley (Shedevr variety), fatty acid composition, gas chromatography

How to cite:

Tartynska, G., Zhuravel, I., Kyslychenko, V., Hutsol, V. (2021). Comparative analysis of the fatty acid composition of raw material of rye (Khamarka variety) and barley (Shedevr variety) of Ukrainian selection. ScienceRise: Pharmaceutical Science, 5 (33), 57-63. doi: http://doi.org/10.15587/25194852.2021.243361

(C) The Author(s) 2021

This is an open access article under the Creative Commons CC BY license hydrate

\section{Introduction}

The leading causes of death in the world, Europe and Ukraine are cardiovascular diseases [1]. This group includes the following diseases: hypertension, coronary heart disease, cerebrovascular disease, as well as disorders due to atherosclerosis [2-4].

According to statistics, the highest mortality rate from coronary heart disease is recorded in Lithuania, Latvia, Hungary, Slovakia, the Czech Republic, Romania, Croatia and Estonia. The highest number of deaths due to cerebrovascular diseases is registered in Bulgaria, Latvia, Romania, Lithuania and Croatia; the smallest number - in France, Spain, Luxembourg, Switzerland, Iceland and Norway. In the Baltics, Romania and Slovenia, more women than men die from cardiovascular diseases. However, more deaths are registered among men in Denmark and Ireland. The lowest gender differences in mortality rates from this group of diseases are characteristic of residents of Cyprus, Spain, the Netherlands, Greece, France and Portugal [1].

In Ukraine, cardiovascular diseases rank second among all diseases, and mortality rates from them are higher than in European countries (for example, in Poland and Germany mortality rate is almost twice less; in Italy - three times) [3,4]. Statistics in recent years show an increase in morbidity among children [5].

That is why prophylaxis of cardiovascular diseases is very important and necessary. Proper eating habits, smoking cessation, regular exercises, bodyweight loss, normalization of blood pressure, lowering cholesterol are important conditions to decrease the risk of cardiovascular diseases [2].

Clinical studies have confirmed that one of the methods of prevention and alternative treatment of cardiovascular diseases is the seafood consumption, plant omega-3 polyunsaturated fatty acids (PUFA) and drugs based on omega-3 PUFA [2, 6, 7].

PUFA importance is recognized in the medical cardiology field. However, recent studies have shown that omega-3 fatty acids can play a useful role in obesity, type 2 diabetes, as well as they can lower the risk of stroke, atherosclerosis, and other cardiovascular diseases [2].

Fatty acids are part of the structural components of cells, tissues and organs; they are involved in the syn- 
thesis of biologically active compounds. Fatty acids have anticoagulant, antihypertensive, hypocholestero-lemic, antioxidant, neuroprotective, cardioprotective, antiinflammatory action, regulate lipid metabolism, improve the conduction of nerve impulses, and promote more efficient brain cells. Some scientists suggest an important role of PUFA in the prevention of various cancers $[2,8]$.

Drugs with omega-3 fatty acids contain eicosapentaenoic, docosahexaenoic and $\alpha$-linolenic fatty acids. They are allowed in some EU countries to prevent heart diseases and to reduce blood lipid levels [6].

Barley (Hordeum vulgare L.) and rye (Secale cereale L.) are annual herbaceous plants from Poaceae family. They are well-known traditional cereals, which are widely cultivated in many countries of the world as cereals and fodder crops [9-11].

Hordeum vulgare $\mathrm{L}$. is the fourth important cereal crop in the world from Poaceae family (after wheat, rice and corn). $60 \%$ of barley harvest is used for livestock fodder, $30 \%$ for the brewing industry to produce the malt, $7 \%$ for seeds and about $3 \%$ for humans' food every year [9].

Secale cereale L. ranks second among cereals used in bread production. Rye grain is used to make flour, rye bread, rye beer, and some types of alcoholic drinks [10, 11].

However, Hordeum vulgare L. and Secale cereale L. can be used for the prevention and the complex treatment of some diseases due to the diversity of their chemical composition. For example, barley contains $\beta$-dglucan, tocopherols, tocotrienols and phenols (proanthocyanidins, flavonols, flavones, chalcones, quinones and derivatives of benzoic and cinnamic acids). Beta-dglucan plays a significant role in prophylaxis of diabetes, cardiovascular disease, hypertension and others according to research results $[8,9]$.

Secale cereale L. grain is rich in dietary fibre, phenolic compounds (polyphenols, flavonoids, phenolic acids (p-coumaric, ferulic, synaptic acids), thiols and sterols. Phenolic compounds act as antioxidants and, accordingly, reduce the risk of cancer, cardiovascular diseases, etc. $[8,10]$. Also, rye grain is rich in unsaturated fatty acids, namely oleic, linoleic and linolenic. Among the dominant elements are potassium, calcium, phosphorus, magnesium [12].

Two varieties are selected for the research namely rye (Khamarka variety) and barley (Shedevr variety), which were included in the State Register of Plant Varieties of Ukraine in 2007. Features of these varieties are winter hardiness, high yields and drought resistance, rapid adaptive properties. Varieties Khamarka and Shedevr are also less susceptible to powdery mildew, brown rust and snow mold than other varieties. Besides, these varieties have sufficient raw material base and high-quality indicators, so they are perspective for pharmacognostic research [13].

Previous studies in these varieties have established and studied the quantitative content of macro- and micronutrients, amino acid composition $[14,15]$.

The aim of the work was to study the fatty acid composition of grains, stalks and leaves of rye (Khamarka variety) and barley (Shedevr variety).

\section{Planning (methodology) of research}

Sowing rye and Common barley are widely cultivated in many countries around the world and various varieties with improved characteristics are selected from them. So, our attention was drawn to new varieties: rye sowing - Khamarka and barley - Shedevr. Their chemical composition has not been studied, so it is important to conduct a pharmacognostic study of plants of these varieties. The study of the fatty acid composition of plants is promising, because this class of compounds has different pharmacological properties, so it was advisable to study the fatty acid composition.

To achieve this goal, the following stages of the experiment were performed:

- Stage 1. Search for literature sources on the distribution, use and chemical composition of Sowing rye (Secale cereale L.) and Common barley (Hordéum vulgáre L.), research of new varieties.

- Stage 2. Selection of materials and method of the research of fatty acid composition of rye (Khamarka variety) and barley (Shedevr variety).

- Stage 3. Carrying out of research by a method of gas chromatography and definition of structure of fatty acids in seeds, stalks and leaves of sowing rye (Khamarka variety) and barley (Shedevr variety).

- Stage 4. Carrying out a comparative analysis of fatty acids accumulation in the studied raw materials for complex study.

\section{Material and method}

\section{1. Plant materials}

New varieties of rye and barley were used for the research. The raw materials were harvested in 2019-2020 in the fields of Plant Production Institute named after V. Ya. Yuryev National Academy of Agrarian of Ukraine.

The research objects were lipophilic extracts of grains, stalks and leaves of rye (Khamarka variety) and barley (Shedevr variety) obtained by exhaustive extraction with hexane.

\section{2. Chemicals and standards}

Standards of saturated and unsaturated fatty acids methyl ethers ("Sigma") were used as reference samples.

\section{3. GC determination of fatty acids}

Method of fatty acids' composition study is based on transformation of triglycerides of fatty acids into their methyl esters and gas chromatographic analysis of the lastmentioned. Analysis of fatty acid composition of studied extracts was carried out by gas chromatography of fatty acids' methyl esters using gas chromatograph "Selmichrom1" (Ukraine) with flame ionization detector. The compounds were separated in gas chromatography column of stainless steel $2.5 \mathrm{~m}$ in length and with inner diameter 4 $\mathrm{mm}$. The column was filled in by stationary phase - inerton, having been processed by $10 \%$ diethylene glycol succinate (DEGS). The following operating parameters were set on the chromatograph: temperature of the column heating oven - $180{ }^{\circ} \mathrm{C}$; vaporizer's temperature $-230{ }^{\circ} \mathrm{C}$; detector's temperature $-220{ }^{\circ} \mathrm{C}$; carrier-gas flow rate (nitrogen) 30 $\mathrm{cm} 3 / \mathrm{min}$; sample volume - from $2 \mathrm{~mm} 3$ solution of acids' methyl ethers in hexane. 
Fatty acids' methyl ethers were identified by comparison of retention time of the sample constituents with Sigma standards of fatty acids. Calculation of methyl ethers' composition was performed by internal normalization method according to the generally accepted procedure. The fatty acids' methyl esters were obtained by the modified Peisker's method. The mixture of chloroform, methanol and sulfuric acid in correlation 100:100:1.

$30-50 \mu \mathrm{l}$ of lipophilic fractions were dispensed into glass ampoules with addition of $2.5 \mathrm{ml}$ of methylating mixture, the ampoules bulbs were sealed and then placed into a thermostat with temperature $105^{\circ} \mathrm{C}$ for 3 hours. After methylation the ampoules were opened, their content was transferred to a test tube with adding zinc sulfate powder on the tip of a scalpel, $2 \mathrm{ml}$ of distilled water and $2 \mathrm{ml}$ of hexane for methyl ethers' extraction. After thorough stirring and decantation, hexane extract was filtered and used for further chromatographic analysis $[16,17]$.

\section{4. Statistical analysis}

Statistical processing and data analysis were performed using Statistic 7.0, Excel 7.0 statistical program package for Microsoft Office for Windows.

\section{Results}

The presented study shows the composition of fatty acids in grains, stalks and leaves of rye - Secale cereale L. (Khamarka variety) and barley - Hordeum vulgare L. (Shedevr variety). Gas chromatograms of fatty acid composition of lipophilic fractions from grains, stalks and leaves of rye and barley are shown in Fig. 1-6. The fatty acid composition of the studied extracts are presented in Table1.

As shown in Table 1, the content of unsaturated fatty acids quantitatively prevails over the content of saturated ones in all studied samples of raw materials. Linoleic and linolenic acids dominate among the unsaturated fatty acids. Palmitic acid prevails among the saturated fatty acids in all types of studied raw materials.

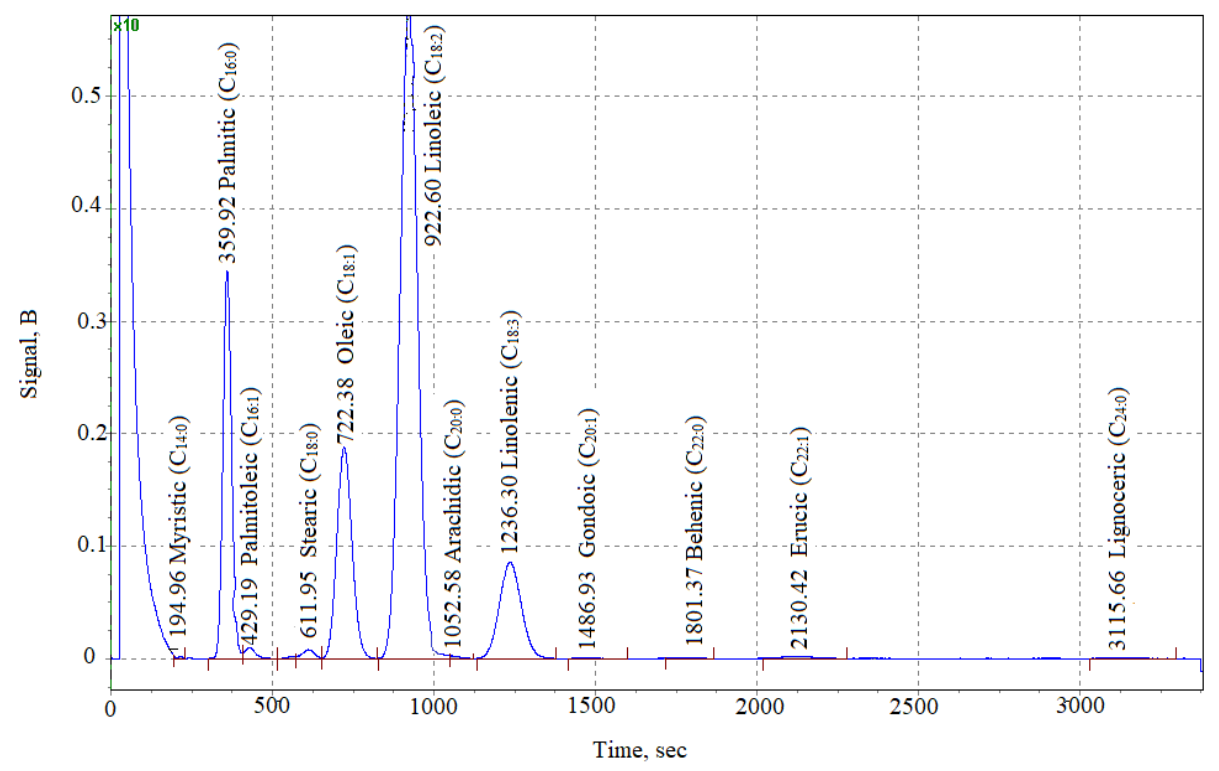

Fig. 1. Gas chromatogram of fatty acid composition in a lipophilic fraction of rye grains (Khamarka variety)

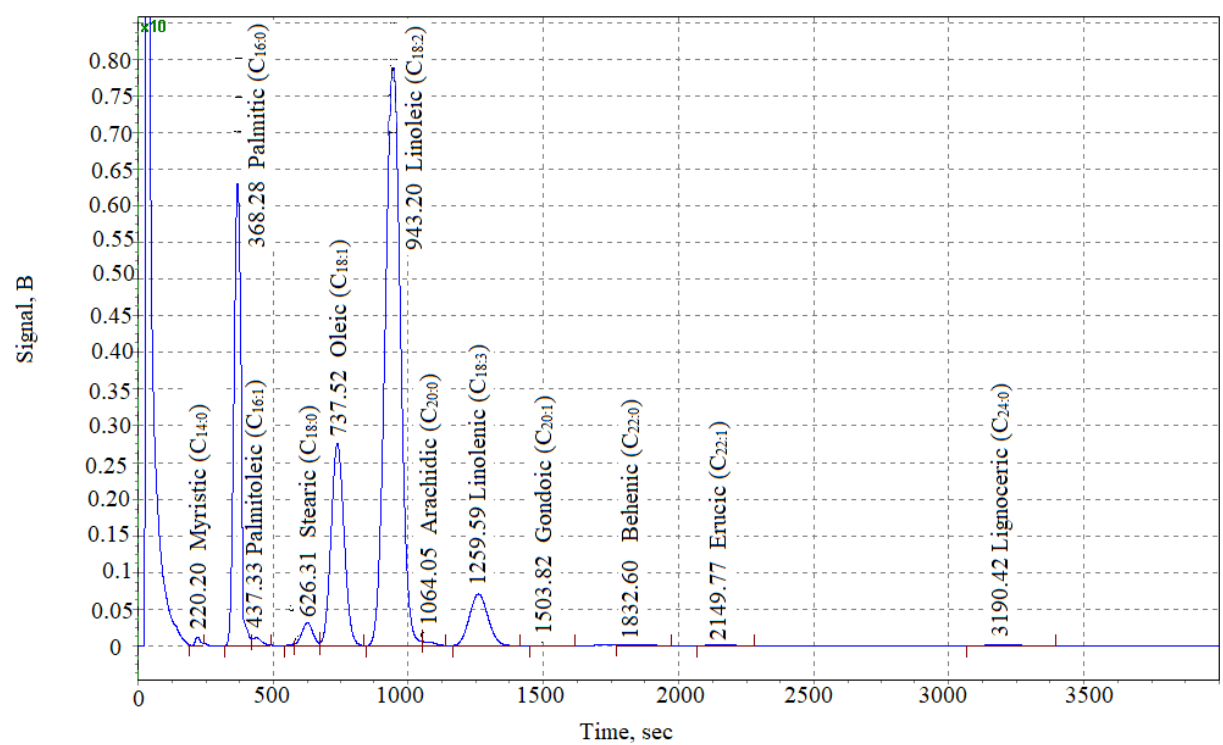

Fig. 2. Gas chromatogram of fatty acid composition in a lipophilic fraction of barley grains (Shedevr variety) 


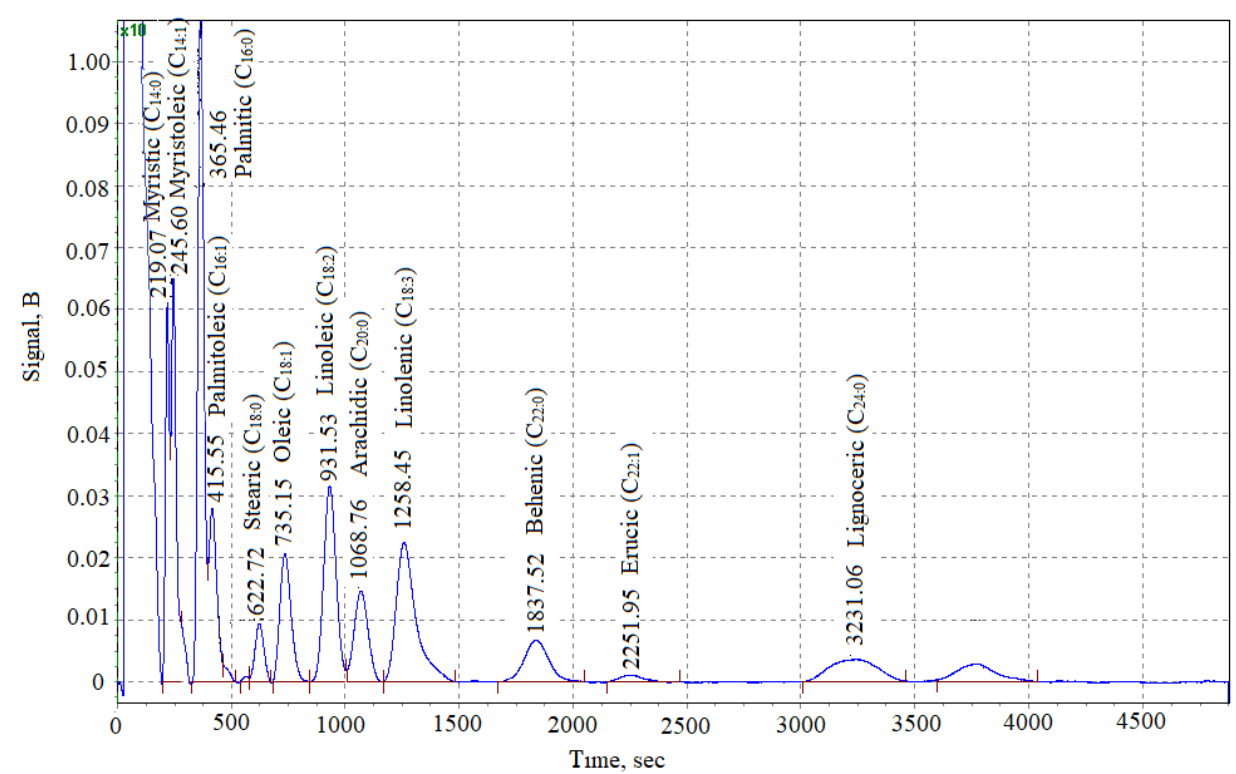

Fig. 3. Gas chromatogram of fatty acid composition in a lipophilic fraction of rye stalks (Khamarka variety)

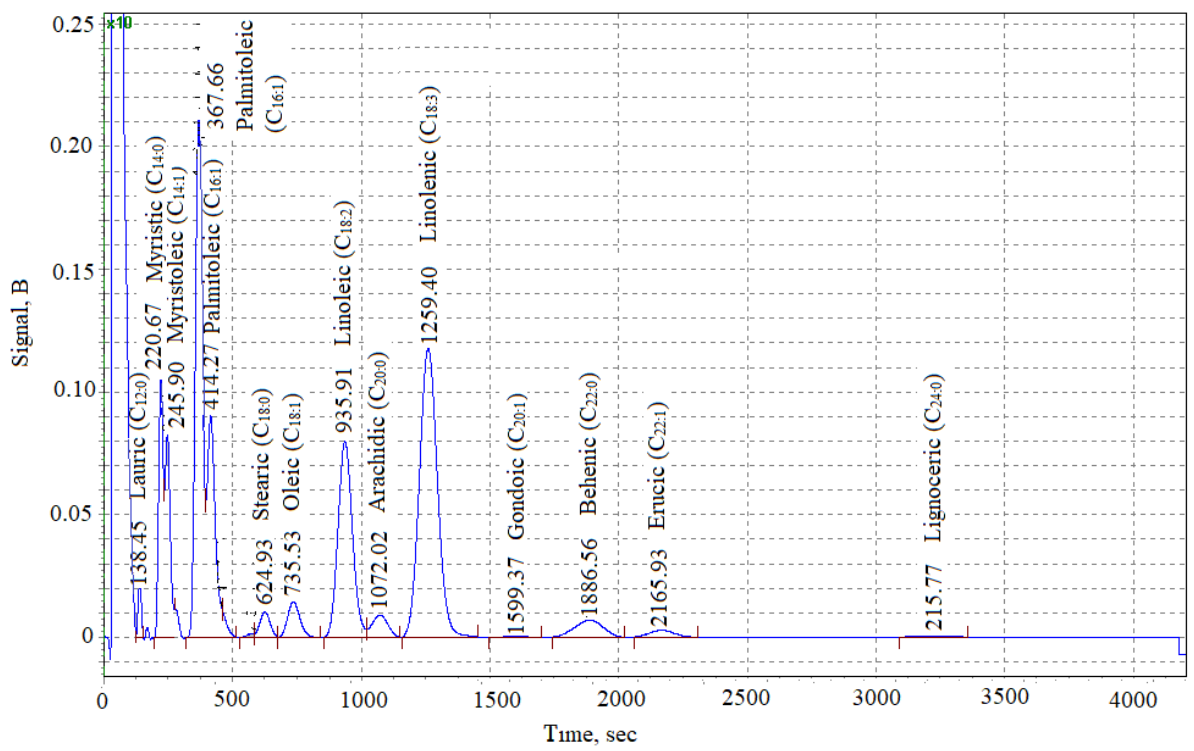

Fig. 4. Gas chromatogram of fatty acid composition in a lipophilic fraction of barley stalks (Shedevr variety)

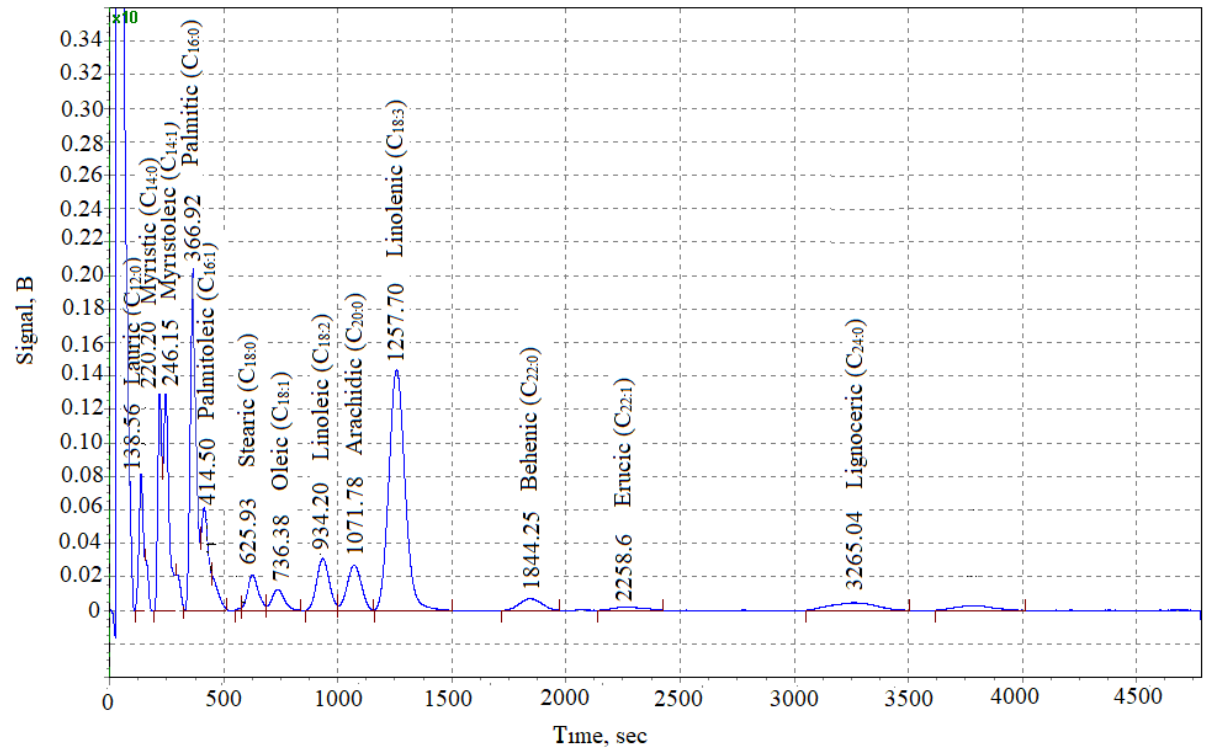

Fig. 5. Gas chromatogram of fatty acid composition in a lipophilic fraction of rye leaves (Khamarka variety) 


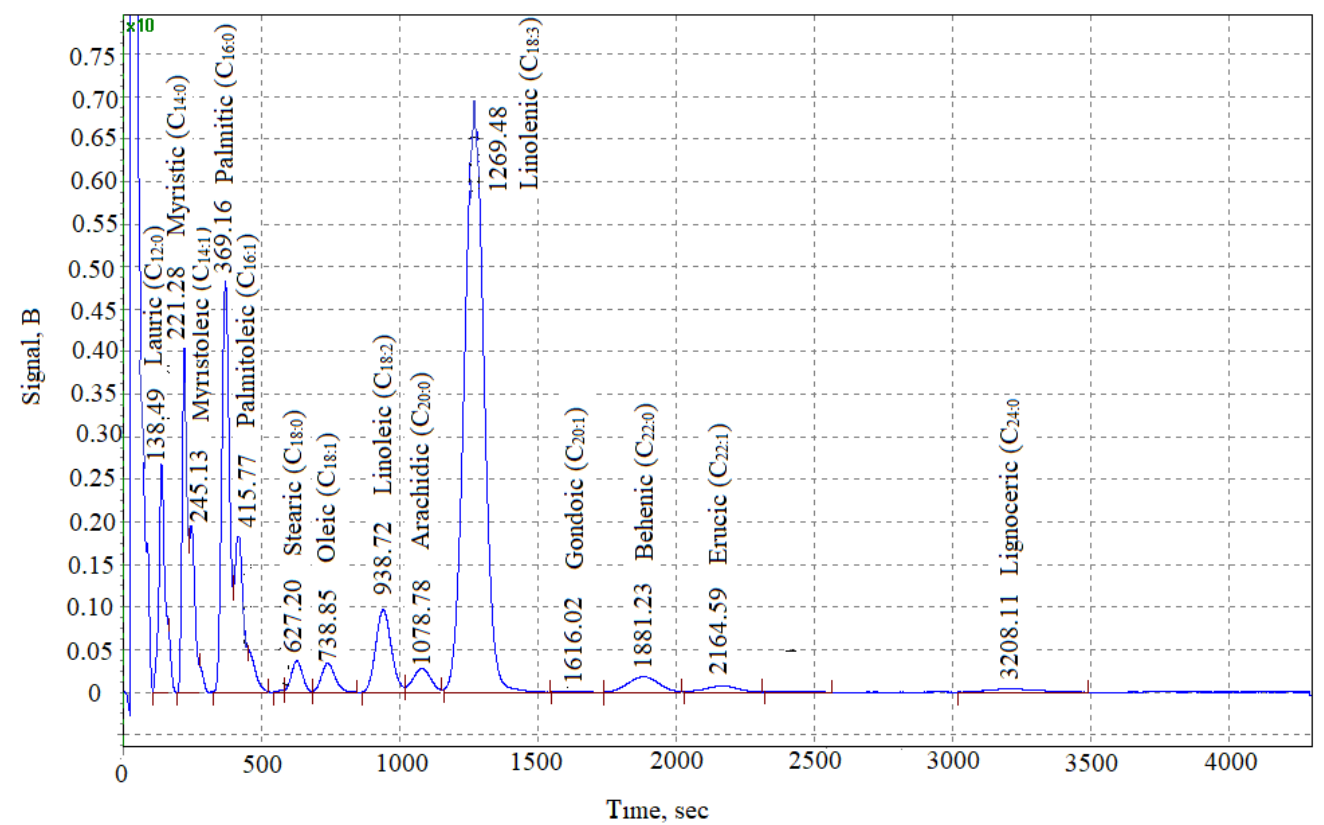

Fig. 6. Gas chromatogram of fatty acid composition in a lipophilic fraction of barley leaves (Shedevr variety)

Table 1

The analysis results of the fatty acid composition of lipophilic extracts of grains, stalks and leaves of rye (Khamarka variety) and barley (Shedevr variety)

\begin{tabular}{|c|c|c|c|c|c|c|c|}
\hline \multirow{3}{*}{ No. } & \multirow{3}{*}{ Fatty Acid } & \multicolumn{6}{|c|}{ Samples No. } \\
\hline & & 1 & 2 & 3 & 4 & 5 & 6 \\
\hline & & \multicolumn{6}{|c|}{ Content in lipophilic fraction, $\%$ of the total } \\
\hline \multicolumn{8}{|c|}{ Saturated fatty acids } \\
\hline 1. & Lauric $\left(\mathrm{C}_{12: 0}\right)$ & - & - & - & $1.00 \pm 0.04$ & $4.82 \pm 0.20$ & $5.00 \pm 0.21$ \\
\hline 2. & Myristic $\left(\mathrm{C}_{14: 0}\right)$ & $0.03 \pm 0.001$ & $0.25 \pm 0.01$ & $8.11 \pm 0.4$ & $7.47 \pm 0.35$ & $8.35 \pm 0.41$ & $8.17 \pm 0.37$ \\
\hline 3. & Palmitic $\left(\mathrm{C}_{16: 0}\right)$ & $16.20 \pm 0.75$ & $21.10 \pm 0.98$ & $19.82 \pm 0.86$ & $20.18 \pm 0.79$ & $16.75 \pm 0.65$ & $13.35 \pm 0.61$ \\
\hline 4. & Stearic $\left(\mathrm{C}_{18: 0}\right)$ & $0.53 \pm 0.02$ & $1.55 \pm 0.07$ & $2.50 \pm 0.11$ & $1.45 \pm 0.07$ & $2.95 \pm 0.13$ & $1.48 \pm 0.07$ \\
\hline 5. & Arachidic $\left(\mathrm{C}_{20: 0}\right)$ & $0.13 \pm 0.005$ & $0.30 \pm 0.01$ & $6.15 \pm 0.27$ & $2.05 \pm 0.09$ & $5.13 \pm 0.24$ & $1.80 \pm 0.08$ \\
\hline 6. & Behenic $\left(\mathrm{C}_{22: 0}\right)$ & $0.06 \pm 0.003$ & $0.25 \pm 0.01$ & $4.78 \pm 0.23$ & $2.76 \pm 0.13$ & $2.12 \pm 0.11$ & $2.04 \pm 0.10$ \\
\hline 7. & Lignoceric $\left(\mathrm{C}_{24: 0}\right)$ & $0.08 \pm 0.004$ & $0.15 \pm 0.006$ & $5.69 \pm 0.25$ & $0.33 \pm 0.01$ & $2.91 \pm 0.13$ & $0.67 \pm 0.03$ \\
\hline \multicolumn{8}{|c|}{ Monounsaturated acids ( $\omega-9)$} \\
\hline 9. & Myristoleic $\left(\mathrm{C}_{14: 1}\right)$ & - & - & $10.75 \pm 0.51$ & $6.47 \pm 0.30$ & $9.40 \pm 0.41$ & $3.72 \pm 0.15$ \\
\hline 10. & Palmitoleic $\left(\mathrm{C}_{16: 1}\right)$ & $0.60 \pm 0.03$ & $0.47 \pm 0.02$ & $7.10 \pm 0.32$ & $10.65 \pm 0.47$ & $6.12 \pm 0.27$ & $6.20 \pm 0.29$ \\
\hline 11. & Oleic $\left(\mathrm{C}_{18: 1}\right)$ & $15.50 \pm 0.71$ & $15.88 \pm 0.68$ & $6.90 \pm 0.31$ & $2.37 \pm 0.11$ & $2.00 \pm 0.09$ & $1.64 \pm 0.7$ \\
\hline 12. & Gondoic $\left(\mathrm{C}_{20: 1}\right)$ & $0.05 \pm 0.002$ & $0.07 \pm 0.003$ & - & $0.12 \pm 0.005$ & - & $0.10 \pm 0.004$ \\
\hline 13. & Erucic $\left(\mathrm{C}_{22: 1}\right)$ & $0.35 \pm 0.01$ & $0.13 \pm 0.006$ & $0.75 \pm 0.02$ & $1.00 \pm 0.05$ & $0.87 \pm 0.04$ & $0.83 \pm 0.03$ \\
\hline \multicolumn{8}{|c|}{ Polyunsaturated acids ( $\omega-3$ and $\omega-6)$} \\
\hline 14. & Linoleic $\left(\mathrm{C}_{18: 2}\right)$ & $56.17 \pm 2.05$ & $53.92 \pm 2.08$ & $11.70 \pm 0.52$ & $15.33 \pm 0.71$ & $5.17 \pm 0.23$ & $5.40 \pm 0.19$ \\
\hline 15. & Linolenic $\left(\mathrm{C}_{18: 3}\right)$ & $10.22 \pm 0.45$ & $5.88 \pm 0.23$ & $11.80 \pm 0.50$ & $28.10 \pm 1.14$ & $30.14 \pm 1.37$ & $48.42 \pm 2.00$ \\
\hline \multicolumn{2}{|c|}{$\begin{array}{l}\text { Total amount of saturated fatty } \\
\text { acids }\end{array}$} & 17.03 & 23.60 & 47.05 & 35.24 & 43.03 & 32.51 \\
\hline \multicolumn{2}{|c|}{$\begin{array}{l}\text { Total amount of unsaturated } \\
\text { fatty acids }\end{array}$} & 82.89 & 76.35 & 49.00 & 64.04 & 53.70 & 66.31 \\
\hline \multicolumn{2}{|c|}{$\begin{array}{l}\text { Total amount of non-identified } \\
\text { fatty acids }\end{array}$} & 0.08 & 0.05 & 3.95 & 0.72 & 3.27 & 1.18 \\
\hline \multicolumn{2}{|l|}{ Total } & 100.00 & 100.00 & 100.00 & 100.00 & 100.00 & 100.00 \\
\hline \multicolumn{2}{|c|}{ Unsaturation ratio } & 4.87 & 3.24 & 1.04 & 1.82 & 1.25 & 2.04 \\
\hline
\end{tabular}

Note: - not identified; 1 - rye grains (Khamarka variety); 2 - barley grains (Shedevr variety); 3 - rye stalks (Khamarka variety); 4 - barley stalks (Shedevr variety); 5 - rye leaves (Khamarka variety); 6 - barley leaves (Shedevr variety)

\section{Discussion}

The study of the fatty acid composition of grains, stalks and leaves of rye (Khamarka variety) and barley (Shedevr variety) was first studied. Compared to previ- ous studies [12], grains of rye (Secale cereale L.) and rye of Hamarka variety contain the same amount of saturated and unsaturated fatty acids, but Hamarka variety accumulates almost $2 \%$ more polyunsaturated acids, namely 
linoleic and linolenic. According to the research, the grains of barley varieties (Giza and C.C89) and the Shedevr variety accumulate almost the same amount of saturated and unsaturated fatty acids, but the fatty acid composition of the Shedevr variety is more diverse [18].

As a result of the study, quantitative content of grains, stalks and leaves of rye (Khamarka variety) and barley (Shedevr variety) for 14 fatty acids in the barley stalks and leaves, 13 fatty acids - in the rye leaves, 12 - in the rye stalks and grains of both varieties, are identified.

As can be seen from Table 1, rye stalks and grains of both varieties contain 6 saturated and 6 unsaturated fatty acids, barley stalks and barley leaves contain 7 saturated and 7 unsaturated fatty acids, and rye leaves 7 saturated and 6 unsaturated fatty acids.

Unsaturated fatty acids are known to increase protective functions of the body, prevent growth of cancer cells, lower cholesterol levels, improve conductivity of nervous impulses and enhance more effective functioning of brain cells, take part in cell membranes formation. Unsaturated fatty acids show F-vitamin activity which improves blood circulation in all body organs and tissues, and, thus, renovation of all human body takes place [19-21].

It is found that unsaturated fatty acids quantitatively prevail in all research objects. Their content in rye grains is $82.89 \%$, in barley grains $-76.35 \%$, in barley stalks $-64.04 \%$, and in barley leaves $-66.31 \%$. However, it should be noted that the advantage of total quantitative content of unsaturated fatty acids over saturated fatty acids is negligible in rye stalks and leaves: $49.00 \%$ vs. $47.05 \%$ and $53.70 \%$ vs. $43.03 \%$, respectively.

In addition to the above properties of unsaturated fatty acids, it should be noted that linoleic and linolenic fatty acids exhibit antimicrobial, antibacterial and antiinflammatory activity [22]. These fatty acids also dominate among other unsaturated acids. Grains of both varieties accumulate the dominant amount of linoleic acid (56.17\% and $53.92 \%$ in rye and barley, respectively). Linolenic acid quantitatively prevails in the other objects among unsaturated fatty acids. Moreover, the highest content of linolenic acid is in rye leaves $(30.14 \%)$ and barley leaves $(48.42 \%)$.

Saturated fatty acids are synthesized by the body, they participate in the construction of cell membranes and the assimilation of vitamins and trace elements, the synthesis of hormones and perform an energy function [23].

Palmitic acid prevails among the saturated fatty acids in all types of studied raw materials. Its maximum amount is accumulated in barley grains $(21.10 \%)$, insignificantly lesser amount - in barley stalks $(20.18 \%)$, then in stalks, leaves and grains of rye $(19.82 \%, 16.75 \%$ and $16.20 \%$ respectively) and barley leaves (13.35\%).

Moreover, it is found that the grains of rye and barley do not contain myristoleic acid, the grains of both varieties and rye stalks do not contain lauric acid, stalks and leaves of rye - gondoic acid.

Study limitations. Additional in-depth study of the fatty acid composition of Sowing rye (Secale cereale L.) and Common barley (Hordéum vulgáre L.) is required, as only those acids whose standard was available have been identified and quantified. In addition, given the statistical importance of the study, it is advisable to study other varieties of Sowing rye (Secale cereale L.) and common barley (Hordéum vulgáre $\mathrm{L}$.)

Prospects for further research. The results obtained prompted an in-depth study of rye (Khamarka variety) and barley (Shedevr variety) raw materials for the purpose of a comparative study and identification of the most promising variety for creating medicinal products based on it.

\section{Conclusions}

The fatty acid composition in grains, stalks and leaves of rye (Khamarka variety) and barley (Shedevr variety) is studied by the gas chromatography method.

14 fatty acids are identified in the stalks and leaves of barley, 13 fatty acids - in the rye leaves and 12 - in the rye stalks and studied grains of both varieties.

The content of unsaturated fatty acids quantitatively prevails over the content of saturated ones in all studied samples of raw materials.

The content of linoleic acid dominates in grains of rye and barley $(56.17 \%$ and $53.92 \%$ of the total, respectively).

Palmitic acid prevails among the saturated fatty acids in all types of studied raw materials.

The obtained data is a part of the complex study of biologically active substances of rye (Khamarka variety) and barley (Shedevr variety), which can be used to create new drugs based on them.

\section{Conflict of interests}

The authors declare that they have no conflicts of interest.

\section{Financing}

The study was performed without financial support.

\section{References}

1. Cardiovascular diseases statistics. Eurostat. Available at: https://ec.europa.eu/eurostat/statistics-explained/index.php?title= Cardiovascular_diseases_statistics

2. Sokoła-Wysoczańska, E., Wysoczański, T., Wagner, J., Czyż, K., Bodkowski, R., Lochyński, S., Patkowska-Sokoła, B. (2018). Polyunsaturated Fatty Acids and Their Potential Therapeutic Role in Cardiovascular System Disorders - A Review. Nutrients, 10 (10), 1561-1582. doi: http://doi.org/10.3390/nu10101561

3. Bulba, P. O., Hubskyi, I. S. (2017). Faktory ryzyku khvorob sertsevo-sudynnoi systemy v ramkakh profilaktychnykh zakhodiv. Aktualni problemy ta perspektyvy rozvytku pryrodnychykh, medychnykh ta farmatsevtychnykh nauk. Zaporizhzhia: ZDMU, 31-33.

4. Buts, M. A. (2016). Terms of origin, prophylaxis and treatment of cardiovascular illnesses of children and teenagers. Molodyi vchenyi, 1, 9-13.

5. Sakhanda, I. V. (2018). Statistics of the incidence of the population as of 01.12.2017 in the context of cardiovascular diseases. Fitoterapiia, 1, 56-58.

6. Omega-3 fatty acid medicines no longer considered effective in preventing heart disease (2019). European Medicines Agency, 1, 19056-19058. 
7. Del Gobbo, L. C., Imamura, F., Aslibekyan, S., Marklund, M., Virtanen, J. K. et. al. (2016) $\omega-3$ polyunsaturated fatty acid biomarkers and coronary heart disease: pooling project of 19 cohort studies. JAMA Internal Medicine, 176 (8), 1155-1166. doi: http://doi.org/10.1161/circ.129.suppl_1.p357

8. Andreasen, M. F., Landbo, A.-K., Christensen, L. P., Hansen, Å., Meyer, A. S. (2001). Antioxidant Effects of Phenolic Rye (Secale cereale L.) Extracts, Monomeric Hydroxycinnamates, and Ferulic Acid Dehydrodimers on Human Low-Density Lipoproteins. Journal of Agricultural and Food Chemistry, 49 (8), 4090-4096. doi: http://doi.org/10.1021/jf0101758

9. Gozukirmizi, N., Karlik, E. (2017). Barley (Hordeum vulgare L.) improvement past, present and future. Brewing Techn?logy. IntechOpen, 49-78. doi: http://doi.org/10.5772/intechopen.68359

10. Kulichová, K., Sokol, J., Nemeček, P., Maliarová, M., Maliar, T., Havrlentová, M., Kraic, J. (2019). Phenolic compounds and biological activities of rye (Secale cereale L.) grains. Open Chemistry, 17 (1), 988-999. doi: http://doi.org/10.1515/chem-2019-0103

11. Chikmawati, T., Miftahudin, Gustafson, J. P. (2013). Rye (Secale cereale L.) and Wheat (Triticum aestivum L.) Simple Sequence Repeat Variation within Secale spp. (Poaceae). HAYATI Journal of Biosciences, 20 (4), 163-170. doi: http://doi.org/10.4308/hjb.20.4.163

12. Bagci, A., Dursun, N., Ozcan, M. M., Tamkoc, A., Ozer, I. (2019). The Oil Yield, Mineral Content, and Fatty Acid Compositions of Some Rye (Secale cereale) Grains. Iranian journal of chemistry and chemical engineering, 38 (5), $285-292$.

13. Derzhavnyi reiestr sortiv roslyn, prydatnykh dlia poshyrennia v Ukraini na 2021 rik (2021). Kyiv: Ministerstvo ahrarnoi polityky ta prodovolstva Ukrainy, 525.

14. Tartynska, G. S., Moeen, F. D., Naeem, S., Zhuravel, I. O., Kyslychenko, V. S., Popyk, A. I. (2018). The study of macro- and microelement composition of rye and barley. Research Journal of Pharmaceutical, Biological and Chemical Sciences, 10 (2), $314-317$.

15. Tartynska, H. S., Zhuravel, I. O., Kyslychenko, V. S., Hutsol, V. V., Martynov, A. V. (2021). Doslidzhennia amino?yslotnoho skladu travy yachmeniu zvychainoho i zhyta posivnoho. Medychna ta klinichna khimiia, 2, 98-103.

16. Pietkova, I. B., Unhurian, L. M., Horiacha, L. M., Kyslychenko, V. S., Zhuravel, I. O., Kuznietsova, V. Yu., Panasenko, O. I. (2020) Composition of fatty acids in Centaurea cyanus (L.). Ceska a Slovenska Farmacie, 69, 194-197.

17. Pinkevych, V. O., Dababneh, M. F., Burda, N. Y., Zhuravel, I. O. (2021). Fatty acid composition of night-scented stock (Matthiola bicornis (Sibth. \& Sm.) DC.) raw materials. Current Issues in Pharmacy and Medical Sciences, 34 (1), $34-41$. doi: http://doi.org/10.2478/cipms-2021-0007

18. Osman, R. O., El-Gelil, F. M. A., El-Noamany, H. M., Dawood, M. G. (2000). Oil content and fatty acid composition of some varieties of barley and sorghum grains. Grasas y Aceites, 51 (3), 157-162. doi: http://doi.org/10.3989/gya.2000.v51.i3.472

19. Magnusdottir, O. K., Landberg, R., Gunnarsdottir, I., Cloetens, L., Åkesson, B., Rosqvist, F. et. al. (2014). Whole Grain Rye Intake, Reflected by a Biomarker, Is Associated with Favorable Blood Lipid Outcomes in Subjects with the Metabolic Syndrome - A Randomized Study. PLoS ONE, 9 (10), e110827. doi: http://doi.org/10.1371/journal.pone.0110827

20. Makhatova, B. G., Datkhayev, U. M., Burda, N. Y., Kyslychenko, V. S. (2016). Fatty acids from Verbascum songaricum herb. Research Journal of Pharmaceutical, Biological and Chemical Sciences, 7 (2), 277-279.

21. Molfino, A., Gioia, G., Fanelli, F., Muscaritoli, M. (2014). The Role for Dietary Omega-3 Fatty Acids Supplementation in Older Adults. Nutrients, 6 (10), 4058-4072. doi: http://doi.org/10.3390/nu6104058

22. Zheng, C. J., Yoo, J.-S., Lee, T.-G., Cho, H.-Y., Kim, Y.-H., Kim, W.-G. (2005). Fatty acid synthesis is a target for antibacterial activity of unsaturated fatty acids. FEBS Letters, 579 (23), 5157-5162. doi: http://doi.org/10.1016/j.febslet.2005.08.028

23. Watson, K. S., Boukhloufi, I., Bowerman, M., Parson, S. H. (2021). The Relationship between Body Composition, Fatty Acid Metabolism and Diet in Spinal Muscular Atrophy. Brain Sciences, 11 (2), 131. doi: http://doi.org/10.3390/brainsci11020131

Received date 30.06.2021

Accepted date 19.10.2021

Published date 29.10.2021

Ganna Tartynska*, PhD, Assistant, Department of Chemistry of Natural Compounds and Nutritiology, National University of Pharmacy, Pushkinska str., 53, Kharkov, Ukraine, 61002

Iryna Zhuravel, Doctor of Pharmaceutical Sciences, Professor, Department of Chemistry of Natural Compounds and Nutritiology, National University of Pharmacy, Pushkinska str., 53, Kharkov, Ukraine, 61002

Viktoriia Kyslychenko, Doctor of Pharmaceutical Sciences, Professor, Head of Department, Department of Chemistry of Natural Compounds and Nutritiology, National University of Pharmacy, Pushkinska str., 53, Kharkov, Ukraine, 61002

Viktoriia Hutsol, PhD, Associate Professor, Department of Pharmacy, National Pirogov Memorial Medical University, Pyrohova str., 56, Vinnytsia, Ukraine, 21018

*Corresponding author: Ganna Tartynska, e-mail: annatartynskaya1984@gmail.com 